\title{
SMPD1 wt Allele
}

National Cancer Institute

\section{Source}

National Cancer Institute. SMPD1 wt Allele. NCI Thesaurus. Code C105020.

Human SMPD1 wild-type allele is located within 11p15.4-p15.1 and is approximately $5 \mathrm{~kb}$ in length. This allele, which encodes sphingomyelin phosphodiesterase protein, is involved in ceramide biosynthesis. Mutation of the gene is associated with Niemann-Pick disease type A and type B. 